\title{
Informacje/Information
}

\author{
DOI : $10.14746 / \mathrm{pp} .2014 .19 .2 .20$

\section{Sprawozdanie z I Kongresu Towarzystw Naukowych pt. Towarzystwa naukowe w Polsce - dziedzictwo, kultura, nauka, trwanie. Warszawa 17-18 września 2013 r.}

Społeczny ruch naukowy w Polsce, sięgający tradycją XV w., tworzony jest obecnie przez ponad 300 towarzystw naukowych, zrzeszających ponad 400 tysięcy działaczy. Oprócz prowadzenia badań naukowych zajmują się oni także szeroko rozumianym upowszechnianiem nauki, realizując swoją bezinteresowną pracą ideę społeczeństwa obywatelskiego. Mimo doniosłej roli, jaką odgrywały towarzystwa naukowe w rozwoju nauki, ich sytuacja nie jest uregulowana pod względem prawnym, a ich znaczenie bywa bagatelizowane przez władze różnych szczebli. Dlatego też zaistniała potrzeba podsumowania dokonań poszczególnych organizacji, co mogłoby stać się podstawą do pogłębionej refleksji na temat miejsca społecznego ruchu naukowego w systemie polskiego państwa. Z tych między innymi przesłanek wynikało zorganizowanie I Kongresu Towarzystw Naukowych pt. Towarzystwa naukowe w Polsce - dziedzictwo, kultura, nauka, trwanie i zaproszenie do dyskusji przedstawicieli społecznych organizacji działających w sferze nauki. Kongres odbył się w Warszawie w dniach 17-18 września 2013 r. Miejscem obrad była siedziba Wydziału Nauk o Żywieniu Człowieka i Konsumpcji Szkoły Głównej Gospodarstwa Wiejskiego (SGGW).

Inicjatywę zorganizowania Kongresu podjęła Rada Towarzystw Naukowych (RTN) przy Prezydium Polskiej Akademii Nauk. Do grona współorganizatorów należeli: Polska Akademia Umiejętności (PAU), Towarzystwo Naukowe Warszawskie i Towarzystwo Naukowe Płockie. Honorowy Patronat nad Kongresem objął Prezydent Rzeczypospolitej Polskiej Bronisław Komorowski. W skład Komitetu Honorowego weszli: Barbara Kudrycka - Minister Nauki i Szkolnictwa Wyższego, Bogdan Zdrojewski - Minister Kultury i Dziedzictwa Narodowego, Krystyna Łybacka - Przewodnicząca Podkomisji Stałej ds. Nauki i Szkolnictwa Wyższego w Komisji Edukacji, Nauki i Młodzieży Sejmu RP, Kazimierz Wiatr - Przewodniczący Senackiej Komisji Nauki, Edukacji i Sportu, Grzegorz Czelej - Przewodniczący Senackiej Komisji Kultury i Środków Przekazu, Michał Kleiber - Prezes Polskiej Akademii Nauk (PAN), Andrzej Białas - Prezes PAU i Wiesław Banyś - Przewodniczący Konferencji Rektorów Akademickich Szkół Polskich. Komitet Naukowo-Programowy stanowili: Anna Gronowska-Senger (przewodnicząca) - Wiceprzewodnicząca RTN, Magdalena Fikus - Przewodnicząca Rady Upowszechniania Nauki przy Prezydium PAN, Andrzej Grzywacz - Prezes Polskiego Towarzystwa Leśnego, Zbigniew Kruszewski - Przewodniczący RTN, Prezes Towarzystwa Naukowego Płockiego, Janusz Lipkowski - Prezes Towarzystwa Naukowego Warszawskiego, Jerzy Majkowski - Prezes Federacji Polskich Towarzystw Medycznych, Ewa Mańkiewicz-Cudny - Prezes Federacji Stowarzyszeń Naukowo-Technicznych NOT, Mirosława Marody - Wiceprezes PAN, Jan Strelau - były Przewodniczący RTN, Alojzy Szymański - Rektor SGGW, Andrzej K. Wróblewski - Wiceprezes PAU. Sponsorowania Kongresu podjął się PKN ORLEN, a patronat medialny objął Program Pierwszy Telewizji Polskiej.

Celem Kongresu było ukazanie wkładu społecznego ruchu naukowego w rozwój kraju i lokalnych społeczności oraz dyskusja nad jego obecnym miejscem i rolą w systemie kultury, dziedzictwa narodowego, nauki, a zwłaszcza jej upowszechniania w Polsce. Dyskusję zaplanowano wokół następujących zagadnień: rozwój i wkład towarzystw naukowych w kształtowanie świadomości narodowej i obywatelskiej na przestrzeni wieków; wpływ towarzystw naukowych na rozwój nauki w Polsce; rola towarzystw naukowych w budowaniu społeczeństwa obywatelskiego; ocena wkładu towarzystw naukowych w upowszechnianie nauki; ocena wkładu społecznego ruchu naukowego 
w rozwój gospodarki regionów i kraju; działania PAN i PAU na rzecz wspomagania społecznego ruchu naukowego w Polsce; rola społecznego ruchu naukowego w rozwoju sektorów chemicznego i rolnego - kluczowych dla gospodarki polskiej; ocena warunków działania aktualnego systemu subsydiowania społecznego ruchu naukowego w Polsce ze środków budżetowych i samorządowych przeznaczonych na naukę; działania Rady Towarzystw Naukowych przy Prezydium PAN w zakresie analizy stanu społecznego ruchu naukowego w Polsce i wypracowanie systemu jego finansowania; potrzeba ustawy o towarzystwach naukowych.

Kongres obradował podczas czterech sesji plenarnych, z których trzy odbyły się 17 września 2013 r., a czwarta, podsumowująca, w dniu następnym. Pierwszej sesji plenarnej pt. Miejsce i rola towarzystw naukowych $w$ systemie nauki w Polsce przewodniczyły Mirosława Marody i Anna Gronowska-Senger. W referacie głównym Henryk Samsonowicz podjął temat rozwoju i wkładu towarzystw naukowych w kształtowanie świadomości narodowej i obywatelskiej na przestrzeni wieków. Podkreślił znaczenie społecznego ruchu naukowego, stwierdzając, ,że bez ukazywania wkładu wielu regionalnych działaczy do szerszej wiedzy o ludziach, o miejscowościach, o ziemiach naszego kraju - mapa polskiej nauki i kultury byłaby bardzo ułomna". Zbigniew Kruszewski w swoim wystapieniu zatytułowanym Rola towarzystw naukowych w budowaniu spoleczeństwa obywatelskiego wymienił szereg palących problemów, z jakimi zmagają się towarzystwa naukowe. Zwrócił m.in. uwagę, ,że zostały one zepchnięte na boczny tor, a ich przyszłość jest poważnie zagrożona”. Przewodniczący RTN stwierdził też, iż „,Społeczny ruch naukowy został sprowadzony na margines instytucjonalnego życia naukowego". Wyraził przekonanie, że nie można rozwijać społeczeństwa obywatelskiego bez uczestnictwa społeczników działających na rzecz nauki. Dlatego też, jego zdaniem, konieczne są uregulowania prawne, chroniące społeczny ruch naukowy. Zwrócił też uwagę na zmarginalizowanie rozwoju nauki i kultury w pierwszych dwudziestu latach transformacji ustrojowej w Polsce, kiedy to władza zajęta była samą sobą oraz rozwojem biznesu. W wyniku tego miejsce wysokiej kultury zajęła prosta rozrywka. Stąd należy uwrażliwić władze oraz społeczeństwo na działania towarzystw naukowych, które właśnie zajmują się przeciwdziałaniem temu złemu zjawisku. W podsumowaniu Z. Kruszewski uznał towarzystwa naukowe za niezbędny w polskiej rzeczywistości czynnik niezależny i twórczy, stwarzający różne możliwości rozwoju, permanentnego kształcenia oraz doskonalenia profesjonalnego. Ostatni referat w pierwszej sesji plenarnej wygłosił Andrzej Grzywacz, a jego wystapienie dotyczyło współdziałania PAN ze społecznym ruchem naukowym.

Tematem drugiej sesji plenarnej była działalność towarzystw naukowych na rzecz upowszechniania nauki. Sesji przewodniczyli Andrzej K. Wróblewski i Marek Kowalczyk. W programie znalazły się następujące referaty: Rada Upowszechniania Nauki w upowszechnianiu nauki Marty Fikus, Rola naukowych towarzystw medycznych w integracji nauki i nanczania Jerzego Majkowskiego, Rola edukacyjna towarzystw naukowych Artura Polloka, Towarzystwo Literackie im. Adama Mickiewicza - sytuacja prawna i finansowa Jacka Wójcickiego i Grażyny Borkowskiej.

W trzeciej sesji plenarnej, której przewodniczyli Ewa Mańkiewicz-Cudny oraz Janusz Lipkowski, dyskutowano na temat Spolecznego ruchu naukowego w rozwoju gospodarczym. Wygłoszono następujące referaty: Wkład spolecznego ruchu naukowo-technicznego w rozwój gospodarczy kraju Ewy Mańkiewicz-Cudny, Udzial towarzystw naukowych w aktywizacji środowisk lokalnych i regionalnych w Polsce Stanisława Kunikowskiego, Towarzystwa naukowe w kontekście europejskiej przestrzeni badawczej Diany Pietruch-Reizes, Działalność Towarzystwa Naukowego Prakseologii na rzecz rozwoju infrastruktury etycznej w polskim biznesie Ryszarda Banajskiego, PKN Orlen jako firma zaangazowana w rozwój innowacji $i$ wspierania nauki Czesława Bugaja.

Czwarta sesja plenarna dotyczyła wspomagania finansowego społecznego ruchu naukowego w Polsce. Przewodniczyły jej Elżbieta Mączyńska i Elżbieta Makulska-Nowak. Podczas tej sesji wygłoszono referaty: 50-lecie Rady Towarzystw Naukowych Tadeusza Majsterkiewicza, Dziatania Rady Towarzystw Naukowych w zakresie systemu finansowania spolecznego ruchu nauko- 
wego Marka Kowalczyka, Udzial ruchu spoleczno-naukowego w doradztwie gospodarczym Elżbiety Mączyńskiej.

Oprócz sesji plaenarnych zorganizowano trzy sesje problemowe: Miejsce $i$ rola towarzystw naukowych $w$ systemie nauki w Polsce, Towarzystwa naukowe w upowszechnianiu nauki, Spoleczny ruch naukowy w Polsce.

W Kongresie wzięli udział przedstawiciele ponad stu towarzystw naukowych. Łącznie wygłoszono 67 referatów, których wysłuchało ponad 200 osób. Organizatorów i uczestników zaszczycili swoją obecnością m.in. senator Kazimierz Wiatr - przewodniczący Senackiej Komisji Nauki, Edukacji i Sportu, senator Sławomir Preiss, poseł Artur Ostrowski - członek Sejmowej Komisji Edukacji, Nauki i Młodzieży, Michał Kleiber - Prezes PAN, Mirosława Marody - Wiceprezes PAN, Andrzej K. Wróblewski - Wiceprezes PAU, Jerzy Wyrozumski Sekretarz Generalny PAU, Katarzyna Chałasińska-Macukow - przewodnicząca Konferencji Rektorów Akademickich Szkół Polskich.

W drugim dniu Kongresu podjęto uchwałę, w której zwrócono uwagę, że społeczny ruch naukowy odgrywa i będzie odgrywał doniosłą rolę w przekształceniach cywilizacyjnych i społecznych. Wyrażono przekonanie, że towarzystwa naukowe są integralną częścią systemu nauki polskiej i w związku z tym powinny znaleźć potwierdzenie swego statusu w polskim systemie prawnym poprzez uchwalenie ustawy o towarzystwach naukowych i stowarzyszeniach naukowo-technicznych. Uznano, że towarzystwa naukowe powinny być wspierane finansowo zarówno podmiotowo, jak i przedmiotowo na szczeblu centralnym ze środków budżetu Państwa oraz na poziomie regionalnym i lokalnym ze środków samorządu województwa, powiatu lub gminy. Uczestnicy Kongresu w uchwale wyrazili przekonanie, że potencjał ekspercki i moralny towarzystw naukowych nie jest obecnie w Polsce należycie wykorzystywany i dlatego apelują o pilną zmianę tej sytuacji. Uchwała została skierowana do Prezydenta RP, Marszałka Sejmu RP, Marszałka Senatu RP, Prezesa Rady Ministrów, Ministra Finansów, Ministra Nauki i Szkolnictwa Wyższego, Ministra Kultury i Dziedzictwa Narodowego i Prezesa PAN.

Listy do uczestników Kongresu skierowały: Ewa Kopacz - Marszałek Sejmu RP i Barbara Kudrycka - Minister Nauki i Szkolnictwa Wyższego, która doceniła rolę towarzystw naukowych w upowszechnianiu wiedzy, rozwoju innowacji, nauki i gospodarki oraz integracji środowisk lokalnych i regionalnych.

\section{U C H W A $\mathbf{L}$ A \\ I Kongresu Towarzystw Naukowych z dnia 18 września 2013 roku}

Uczestnicy I Kongresu Towarzystw Naukowych, zwolanego do Warszawy pod hastem ,, Towarzystwa naukowe w Polsce - dziedzictwo, kultura, nauka, trwanie", reprezentujqcy ponad 350 towarzystw naukowych, skupiajqcych wiele tysięcy osób, stwierdzajq, że Polska w pierwszej polowie XXI wieku stoi przed koniecznościq szybszego rozwoju cywilizacyjnego. Rozwój ten możliwy jest w oparciu o spoleczeństwo demokratyczne, obywatelskie, o spoleczeństwo wiedzy. Doniosta role w tych przeksztalceniach cywilizacyjnych i spolecznych odgrywa i będzie odgrywać spoleczny ruch naukowy i naukowo-techniczny. W czasach zaborów to jemu wlaśnie zawdzięczaliśmy uchronienie naszej Ojczyzny przed cywilizacyjna kolonizacjq, a po odzyskaniu niepodlegtości stat się zalqżkiem odrodzenia struktur instytucjonalnych nauki polskiej i podtrzymywat ich funkcjonowanie jako wazny czynnik integracji spoleczeństwa.

Kongres potwierdza, $\dot{z} e$ :

- towarzystwa naukowe $i$ stowarzyszenia naukowo-techniczne jako spoteczne, pozarzadowe organizacje naukowe sa integralna czesścia i jednym z filarów kultury 
i nauki polskiej także w niepodlegtej Polsce, stanowiqc obywatelski fundament w środowisku nauki i nauczania;

- towarzystwa naukowe $i$ stowarzyszenia naukowo-techniczne funkcjonuja w oparciu o swych zaangażowanych spolecznie czlonków, którzy jako wolontariusze gotowi sa do podejmowania zadan na rzecz szeroko rozumianej kultury, nauki, oświaty $i$ ich promocji;

- towarzystwa naukowe $i$ stowarzyszenia naukowo-techniczne dzialaja:

- interdyscyplinarnie, laczac ludzi z różnych lokalnych środowisk naukowych $i$ zawodowych;

- ponadlokalnie, w tym międzynarodowo, laczqc środowiska naukowe zwiqzane $z$ określona dziedzina lub dyscyplinq naukowa;

- inicjujac $i$ weryfikujac badania naukowe;

- integrujaco $w$ nauce $i$ ksztatceniu.

Kongres uznaje, że towarzystwa naukowe $i$ stowarzyszenia naukowo-techniczne wypetniaja swoje cele i zadania między innymi poprzez:

- prowadzenie badań naukowych, w tym badań nad regionem;

- ksztalcenie ustawiczne;

- organizowanie kongresów oraz konferencji międzynarodowych, krajowych, regionalnych i lokalnych;

- prowadzenie dzialalności wydawniczej;

- prowadzenie bibliotek, muzeów, archiwów i innych;

- promowanie i popularyzację kultury, nauki oraz techniki;

- podejmowanie audytów badań naukowych i eksperckich,

- podejmowanie projektów na rzecz innowacji w gospodarce;

- wspomaganie kadry naukowej i technicznej w jej rozwoju i zwiększeniu mobilności,

- dbanie o etykę zawodowa.

Kongres wyraza przekonanie, ze towarzystwa naukowe i stowarzyszenia naukowo-techniczne jako integralna część systemu nauki polskiej powinny znaleźć potwierdzenie swego statusu w systemie prawnym obowiqzujacym w Polsce poprzez ustawę o towarzystwach naukowych $i$ stowarzyszeniach naukowo-technicznych; winny być także wspierane finansowo zarówno podmiotowo, jak i przedmiotowo na szczeblu centralnym ze środków budzetu Państwa oraz regionalnie i lokalnie ze środków samorzqdu województwa, powiatu lub gminy - w zależności od celów i zadań, jakie realizujq, a także przez organizacje spoleczne i gospodarcze, na rzecz których wykonujq określone zadania.

Kongres wyraza przekonanie, że potencjal ekspercki i moralny towarzystw naukowych i stowarzyszeń naukowo-technicznych nie jest należycie wykorzystywany w Kraju i apeluje o pilnq zmiane tej sytuacji.

Majac powyższe na uwadze, Kongres kieruje niniejszq Uchwate do Prezydenta RP, Marszalka Sejmu RP, Marszatka Senatu RP, do Prezesa Rady Ministrów, Ministra Finansów, Ministra Nauki i Szkolnictwa Wyższego, Ministra Kultury i Dziedzictwa Narodowego, Prezesa PAN, wnoszqc jednocześnie o podjęcie dzialań majacych na celu wypracowanie zasad polityki państwa w stosunku do spolecznego ruchu naukowego i naukowo-technicznego oraz umocnienia miejsca i roli towarzystw $i$ stowarzyszeń naukowych (towarzystw ogólnych i regionalnych, specjalistycznych towarzystw naukowych, stowarzyszeń naukowo-technicznych) w systemie nauki oraz wprowadzenia rozwiqzań prawnych umożliwiajqcych zapewnienie funkcjonowania i rozwoju spolecznego ruchu naukowego i naukowo-technicznego w Polsce.

Warszawa, dnia 18 września 2013 roku. 